\title{
Thirteen ways of looking at a blackbird
}

\section{WALLACE STEVENS}

I

Among twenty snowy mountains,

The only moving thing

Was the eye of the blackbird.

II

I was of three minds,

Like a tree

In which there are three blackbirds.

\section{III}

The blackbird whirled in the autumn winds.

It was a small part of the pantomime.

\section{IV}

A man and a woman

Are one.

A man and a woman and a blackbird

Are one.

\section{$\mathrm{V}$}

I do not know which to prefer,

The beauty of inflections

Or the beauty of innuendoes,

The blackbird whistling

Or just after.

\section{VI}

Icicles filled the long window

With barbaric glass.

The shadow of the blackbird

Crossed it, to and fro.

The mood

Traced in the shadow

An indecipherable cause.

\section{VII}

$O$ thin men of Haddam,

Why do you imagine golden birds?

Do you not see how the blackbird

Walks around the feet

Of the women about you? 


\section{Treze modos de olhar para um pássaro preto}

Tradução de DaVi ArrigucCiJR.

I

Entre vinte montanhas de neve,

O único movente

Era o olho do pássaro-preto.

II

Eu estava entre três idéias

Feito uma árvore

Em que há três pássaros-pretos.

III

O pássaro-preto revoava no vento de outono.

Era uma pequena parte da pantomina.

IV

Um homem e uma mulher

São um.

Um homem e uma mulher e um pássaro-preto

São um.

$\mathrm{V}$

Não sei mesmo qual preferir:

A beleza das inflexões

Ou a das alusões,

O pássaro-preto assobiando

Ou só depois

VI

O gelo recobria a longa janela

De rudes cristais.

A sombra do pássaro-preto

Passava de lá para cá.

A sensação

Traçou na sombra

Uma causa indecifrável.

VII

Ó finos homens de Haddam,

Por que imaginais pássaros dourados?

Acaso não vedes o pássaro-preto

Rondando os pés

das mulheres tão perto? 


\section{VIII}

I know noble accents

And lucid, inescapable rhythms;

But I know, too,

That the blackbird is involved

In what I know.

IX

When the blackbird flew out of sight,

It marked the edge

Of one of many circles.

$\mathrm{X}$

At the sight of blackbirds

Flying in a green light,

Even the bawds of euphony

Would cry out sharply.

XI

He rode over Connecticut

In a glass coach.

Once, a fear pierced him,

In that he mistook

The shadow of his equipage

For blackbirds.

XII

The river is moving.

The blackbird must be flying.

XIII

It was evening all afternoon.

It was snowing

And it was going to snow.

The blackbird sat

In the cedar-limbs. 
VIII

Sei de nobres cadências

De ritmos lúcidos, inescapáveis;

Mas, sei também

Que o pássaro-preto

Está envolvido no que sei.

IX

Quando voou a se perder de vista,

O pássaro-preto marcou a margem

De um de muitos círculos.

$\mathrm{X}$

À vista dos pássaros-pretos

Voando na luz verde,

Até as alcoviteiras da eufonia

Gritariam de espanto.

XI

Ele andava por Connecticut

Num carro de vidro.

Uma vez ficou varado de medo;

Foi que tomou

A sombra da carruagem

Por pássaros-pretos.

XII

O rio vai fluindo

O pássaro-preto deve ir voando.

XIII

Era noite a tarde toda.

Estava nevando

E ainda ia nevar.

O pássaro-preto sentou

No galho do cedro. 